\title{
A Note on Reproductive Behavior in the Buff-striped Keelback, Amphiesma stolatum (Linnaeus 1758), in India
}

\author{
Rahul Vinod Maraskolhe
}

194, Vrindavan Nagar, Binaki Lay-out, Dr. Ambedakar Marg, Nagpur - 440017, India (rmdya24@gmail.com)

T The Buff-striped Keelback (Amphiesma stolatum) is widely distributed throughout mainland India, Pakistan, Nepal, Bhutan, Bangladesh, and Sri Lanka (Smith 1943; Whitaker and Captain 2004) and is frequently encountered in the Nagpur District of Maharashtra (Deshmukh et al. 2015). These abundant, diurnally active snakes frequent paddy fields, ponds, thick grass, and gardens, and are known to estivate in hot and hibernate in colder areas (Smith 1943; Whitaker and Captain 2004). Five to ten eggs are laid during the months from May to September (Smith 1943). Herein I document mating immediately after a female deposited a clutch of seven eggs.

At 1235 h on 12 August 2018, during rescue operation at Chitrashala Nagar, near Pratibha Celebration Lawn, Kalamana, Nagpur, Maharashtra, India $\left(21^{\circ} 16^{\prime} 44.52^{\prime \prime} \mathrm{N}\right.$, $79^{\circ} 14^{\prime} 40.91$ ”E), I encountered three Buff-striped Keelbacks. I rescued an adult, obviously gravid female $(380 \mathrm{~mm}$ total length) and placed it into a plastic container. The female almost immediately began laying eggs. In approximately 20 min the female laid seven fertile, fully developed eggs (ave. $24.2 \times 13.6 \mathrm{~mm}$ ). I subsequently rescued an adult male (344 $\mathrm{mm})$ and a young male $(270 \mathrm{~mm})$ and placed them in the container with the female. Shortly thereafter I noticed the female, which had just laid seven eggs, mating with the adult male

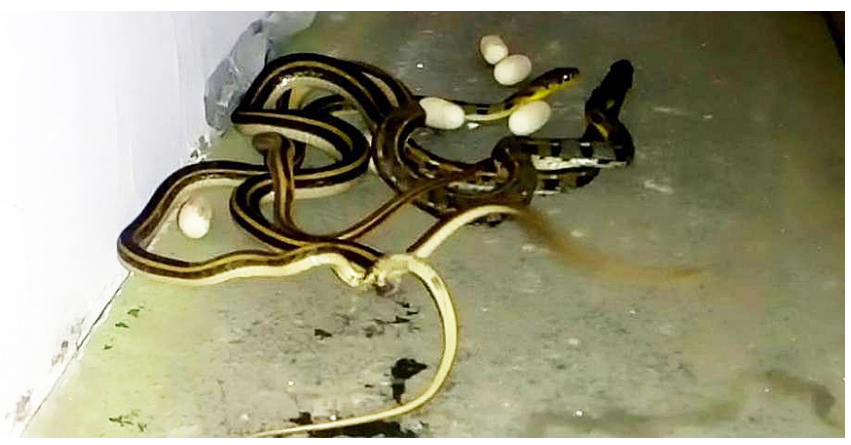

Fig. 1. Mating Buff-striped Keelbacks (Amphiesma stolatum). Note the seven recently deposited eggs.
(Fig. 1). Mating lasted approximately $2.5 \mathrm{~h}$, during which the young male rubbed its hemipenes on the genitals of the mating pair. I placed the seven eggs under logs in a nearby forested area and released all three snakes in the outskirts of Nagpur.

In nature, males detect females using subtle cues such as pheromonal trails deposited on the substrate, and follow these trails to locate the females (e.g., Mason 1992). Multiple males attracted to the same female will compete, and small males may avoid larger competitors by waiting nearby to court the female after the larger rival has departed (Madsen et al. 1993). I cannot say whether the males were searching for the female when I found them, but the behavior of the smaller male might reflect an inability to compete directly for access to the female. The receptivity of the female immediately after ovipositioning, at a time when her energy reserves are likely depleted, might be explained by the fact that many snakes can store sperm for extended periods (e.g., Seigel and Ford 1987).

\section{Acknowledgement}

I am very grateful to Kunal Jarvia, Vishal Dambhare, and Rewati Rajan for their help and support.

\section{Literature Cited}

Deshmukh, R.V., S.A, Deshmukh, and S.A. Badekar. 2015. Rescued records of snakes from Nagpur District, Maharashtra with data on unrecorded species. Reptile Rap 17: 34-43.

Madsen, T., R. Shine, J. Loman, and T. Hakansson. 1993. Determinants of mating success in male adders, Vipera berus. Animal Behaviour 45: 491-499.

Mason, R.T. 1992. Reptilian pheromones, pp. 114-228. In: C. Gans and D. Crews (eds.), Biology of the Reptilia. Volume 18, Physiology E. Hormones, Brain, and Behavior. University of Chicago Press, Chicago, Illinois.

Seigel, R.A. and N.B. Ford. 1987. Reproduction ecology, pp. 210-252. In: R.A. Seigel, J.T. Collins, and S.S. Novak (eds.), Snakes: Ecology and Evolutionary Biology. Macmillan, New York, New York.

Smith, M.A. 1943. The Fauna of British India, Ceylon and Burma, Including the Whole of the Indo-Chinese Sub-region. Reptilia and Amphibia. Vol. III.Serpentes. Taylor and Francis, London,UK.

Whitaker R. and A. Captain. 2004. Snakes of India: The Field Guide. Draco Books, Chennai, India. 